\title{
Septiembre de 1810 \\ Recomponer el pacto, formar ¿qué nación?
}

\author{
Mariana Terán Fuentes ${ }^{(\star)}$
}

\section{Resumen}

El ensayo centra la atención en la dimensión política de la crisis de la monarquía española de 1808 que tuvo, en su recomposición, dos vías de manifestación: las guerras de insurgencia y la reunión de los diputados en el Puerto de Cádiz. Para el caso del virreinato de la Nueva España las dos vías coincidieron en sus inicios en septiembre de 1810. De su confluencia se fueron definiendo los principales parámetros de los elementos rectores de las nuevas naciones.

Palabras clave: nación, soberanía, constitución, república, insurgencia.

\section{Abstract}

The essay focuses on the political dimensión of the crisis of the Spanish monarchy in 1808 had, in its reorganization, two ways of manifestation: the wars of insurgency and the meeting of deputies in the port of Cadiz. In the case of the viceroyalty of New Spain, the two tracks agreed its inception in September 1810. From its junction were defined the main parameters governing elements of the new nations.

Key words: nation, sovereignty, constitucion, republic insurgency.

(*) Universidad Autónoma de Zacatecas, México.

ص Recibido: octubre de 2011 - Aprobado: diciembre de 2011 


\section{8: La crisis de soberanía, un problema común para la monarquía española}

La historiografía sobre el liberalismo gaditano ha coincidido en que 1808 fue el año de una gran conmoción política en el mundo no sólo peninsular, sino monárquico español en su conjunto. La ocupación militar de Napoleón Bonaparte representó un factor externo que devino en una crisis en el mundo español expresada a través de múltiples muestras de adhesión a Fernando VII y a la conservación de la monarquía española. También se ha coincidido en que de este acontecimiento de carácter extraordinario, se desencadenó el problema de la soberanía. La opinión generalizada en el imaginario político de la época desconoció la figura del emperador francés, lo calificó de usurpador, tirano y exponente del anticatolicismo. La monarquía católica resistió con su rechazo explícito a Napoleón; mostró un patriotismo exaltado por su deseado monarca y se preguntó por la soberanía. Se trataba de la concepción monista, según la cual el monarca era el que asumía la suprema potestad en su indisoluble unidad.

Según Miguel Artola, el origen de la crisis está tanto en la pretensión de Napoleón por imponer su poder sobre Europa, como en la debilidad de los reyes españoles. ${ }^{1}$ Napoleón le pidió a su hermano José que ocupara el trono español asegurándole la importancia que revestía: "España no es lo que el reino de Nápoles, se trata de once millones de habitantes, de más de 150 millones de ingresos sin contar con las numerosas rentas y posesiones de América". ${ }^{2}$ Mandó publicar en la Gaceta de Madrid la convocatoria a celebrar una diputación general que se daría cita en la ciudad de Bayona para establecer el nuevo orden jurídico que regiría a la monarquía española. Una vez proclamado José Bonaparte rey de España e Indias, se reunieron 65 diputados para elaborar lo que se conoció como la Constitución de Bayona del 6 de julio de 1808. Como lo ha explicado Miguel Artola, fue un documento de vanguardia que si hubiese tenido una mayor posibilidad temporal de ejercerse, habría causado una verdadera transformación en el orden social, pues se establecía la supresión de los privilegios, la abolición del tormento, la admisibilidad de empleos, la representación en Cortes, la unidad de códigos, ${ }^{3}$ entre otras medidas, bajo la permanencia de la religión católica, como la religión de Estado. ${ }^{4}$ Muchos de los españoles reformistas la juraron porque veían en ella la concreción de sus aspiraciones ilustradas. La obra legislativa de la Constitución de Bayona fue objeto de descrédito no por su contenido doctrinario que en aspectos centrales heredó a la Constitución de 1812, sino por la manera en que

\footnotetext{
Miguel Artola, Historia de España. La burguesía revolucionaria (1808-1874), Madrid, Alianza ed, 2006, p. 17.

La cita es tomada de M. Artola, Historia de España, p. 24.

M. Artola, Historia de España, p. 26.

4 La Constitución de Bayona significaba la ruptura con el orden prevaleciente al abolir privilegios, dotar de derechos a los individuos como los de libertad y seguridad. Sin dejar de mantener la división social estamentaria, el principal eje novedoso fue la recomposición de la relación entre el monarca y la nación. Manuel Suárez Cortina, "El liberalismo revolucionario en la quiebra de la monarquía hispánica" (MS en prensa).
} 
fue impuesta. No tuvo legitimidad porque quien la mandó elaborar gozaba de un generalizado rechazo.

De manera simultánea se organizaron en el nivel provincial las juntas con el fin de guardar en depósito la soberanía hasta en tanto el monarca regresara al trono. La base jurídica en la que descansó esta respuesta fue común al mundo español: el pacto traslatii: en ausencia del monarca, la soberanía regresaba al pueblo.

Historiadores como José María Portillo Valdés explicaron este cisma político a través de una crisis triple: dinástica, de soberanía y constitucional. ${ }^{5}$ Crisis expresada en unos cuantos años: 1808-1812. La serie de abdicaciones de la corona española fueron el síntoma de la crisis dinástica. A pesar de que Napoleón hiciera todo lo posible porque su hermano José tomara su lugar en la monarquía española con una Constitución de vanguardia que hablaba de representación, Cortes y estado centralizado, el movimiento juntero y las diversas muestras de rechazo expresadas en correspondencia, gacetas, proclamas y actas de cabildo, hicieron manifiesta su negativa a la imposición de una soberanía extranjera. Los estudiosos sobre el constitucionalismo hispano reconocen la innovación legislativa del conjunto doctrinario napoleónico, sin embargo, los juristas españoles recurrieron a la tradición legal hispana para proponer un continuismo histórico que le diera sustento teórico a la formulación legislativa y autónoma de la tradición española. Esto evitó que el discurso constitucional hispano de 1812 no fuera una copia o resultado de influencias extranjeras, ${ }^{6}$ sino una edición original constitucionalista viable cuyo mejor modelo de referencia lo encontró en su propia historia.

El cautiverio del monarca no fue significativo por la crisis dinástica en sí misma, sino por lo que desencadenó: la crisis de soberanía. Ese fue el verdadero golpe que recibió la casa de los Borbón. A pesar de que se ha reconocido la personalidad endeble del sucesor de Carlos Iv, la coyuntura histórica de su cautiverio propulsó un patriotismo inusitado. La imagen del monarca cautivo fue el preámbulo de una asombrosa retórica de la patria católica. La única soberanía reconocida y legitimada por ayuntamientos, pueblos y corporaciones, era la que ocupaba hasta entonces el monarca español. ${ }^{7}$

La representación organicista de la monarquía que sintetizó Benito Jerónimo de Feijoo en su Teatro crítico universal, colocaba al rey en la cabeza del cuerpo. Sin

\footnotetext{
5 José María Portillo Valdés, Revolución de nación. Orígenes de la cultura constitucional en España, 17801812, Madrid, Centro de Estudios Políticos y Constitucionales ed, 2000, pp. 159-258.

6 Manuel Suárez Cortina, "El liberalismo revolucionario en la quiebra de la monarquía hispánica". En este ensayo se aclara que no se trató de restaurar el viejo orden, sino de volver a la tradición como epicentro para fundamentar el viraje que en ese momento y bajo las condiciones particulares de guerra, debía orientar las reflexiones legislativas: "El historicismo liberal utilizaba la historia de un modo distinto pues su cometido no era restaurador, sino dar legitimidad histórica a las nuevas instituciones".

7 M. Artola, en especial, "La crisis de la monarquía absoluta y la guerra de Independencia", Historia de España. La burguesía revolucionaria, pp. 17-33.
} 
cabeza reconocida y legitimada por el resto del cuerpo, qué concepción de órgano político podía asumir la nueva realidad del conjunto monárquico español. Ese fue el problema que resultó ser el eje de la reorganización de la vida jurídica e institucional entre 1808-1809.

Una de las respuestas fue la instalación de las juntas provinciales a través de un movimiento territorial centrífugo, que amenazaban con fragmentar la unidad. Cada provincia se gobernaba a sí misma y con ello se perdía la articulación que debía ligar al conjunto. El archipiélago amenazaba.

Sin embargo, con el establecimiento de la Junta Central, se logró reconcentrar el poder en una sola institución, a la cual cabildos tanto de la península como de la América Española, le ofrecieron muestras de obediencia, adhesión y lealtad. El momento singular de crisis dinástica y de soberanía, hizo que se convocara a representantes de ambos hemisferios para integrar la Junta. Se trató de la primera experiencia monárquica en ambos lados del Atlántico de un proceso electoral que involucró a las provincias de la América española. Como lo ha destacado Marcello Carmagnani, la Junta Central representó un momento de discontinuidad en la cultura política española al concebirse como un órgano de carácter nacional donde podían ser escuchados los intereses de la provincia. ${ }^{8}$

La Junta mandó dar a conocer a los diferentes reinos su posición respecto a los acontecimientos recientes y su rechazo a la Constitución de Bayona: "Querer hacernos creer que se puede sentar el edificio moral de la libertad y forma de una nación sobre cimientos amenazados con usurpación, iniquidad y alevosía... Pero el pueblo español, en cuyo seno se habían conocido, primero que en otro alguno de los modernos los verdaderos principios del equilibrio social". ${ }^{9}$ Escritores y teóricos del derecho, como Francisco Martínez Marina o Guarino y Sempere coincidieron en que el principal ajuste que requería la monarquía española para enfrentar esta crisis de soberanía, estaba en la reunión a Cortes Generales.

El importante papel que jugó la Junta Central entre el 25 de septiembre de 1808 y el 31 de enero de 1810 se puede sintetizar en cuatro elementos que ayudaron a dar unidad a la patria española: a) su autodesignación como la institución que guardaba en depósito la soberanía del monarca y el reconocimiento que obtuvo de villas, ciudades y pueblos del conjunto español lo que le dio un amplio margen de legitimidad; b) su explícita intención de reconcentrar el poder y establecer medidas de carácter urgente para salvaguardar a la monarquía del vecino usurpador; c) su discurso político que habló en pos de la nación española. La nación española venía a ser, en esta coyuntura, el embrión del nuevo sujeto político en el mundo hispanoamericano; d) la afirmación de que la

\footnotetext{
8 Marcello Carmagnani, El Otro Occidente. América Latina desde la invasión europea hasta la globalización, México, FCE/El Colegio de México/Fideicomiso Historia de las Américas eds, 2004, p. 122.

9 "Comunicado de la Junta Suprema del reino de la nación española a sus habitantes", Sevilla, 25 de octubre de 1809.
} 
nación española estaba compuesta por dos hemisferios: España y América, por tanto, América perdía la condición de factoría o colonia, y se volvía un conjunto heterogéneo de reinos con los mismos derechos de representación que España.

A pesar de que la historiografía ha reparado en la desigual condición de representación americana, el momento histórico dio cuenta de que en la defensa de la nación española y en la urgencia de reconcentrar el poder, se abría un horizonte para dotar de existencia territorial al nuevo sujeto en Hispanoamérica: la nación.

¿Cómo asegurar la soberanía de la nación? Esa fue la preocupación más importante de entonces. La voluminosa obra de Francisco Martínez Marina, la Teoría de las Cortes, cumplió su cometido: recordar que las Cortes y las Constituciones "se hallan en los bosques", es decir, en la vieja tradición visigótica española. La monarquía había dado muestras, desde su tradición medieval, de que las Cortes, si bien habían ejercido su función como consejeras del rey y mediado su actuación, ahora podían representar el importante papel legislativo de dar cuerpo a la nación española. El tratadista español recordaba que el pacto de la monarquía era justo eso, un convenio de asociación para garantizar el bien común, que ponía en recíproca obligación a los gobernantes y a los gobernados:

La asociación civil es efecto de un convenio, la regalía de un oficio instituido en beneficio público, los reyes son hechura de los pueblos cuya voluntad les dio el ser y cuyos dones y trabajos los mantienen. La extensión de la autoridad regia, sus modificaciones y restricciones penden de aquel convenio, de la constitución del Estado y de la voluntad del pueblo en quien reside originariamente toda autoridad pública. ${ }^{10}$

Si bien Martínez Marina avanzaba sus trabajos para hacer necesaria la reunión de representantes en Cortes, ilustrados como Jovellanos buscaron impedirla. Jovellanos apreció con claridad el peligro de que se juntaran las Cortes sin la anuencia del monarca: el poder compartido. Sólo el monarca detentaba la soberanía. Ningún otro organismo o institución podía adjudicársela. Las Cortes no podían participar del poder si no era exclusivamente con la anuencia del monarca. ${ }^{11}$

A pesar del temor manifestado por Jovellanos, el 25 de septiembre de 1810 se reunieron — sin la anuencia del rey - los diputados de ambos hemisferios en la Isla de León para discutir jurídicamente la conformación de la nación española. El tema de su tiempo fue la legislación. Como decía Cayetano Filangieri, la

\footnotetext{
10 Francisco Martínez Marina escribió durante la primera década del siglo XIX su Teoría de las Cortes o grandes Juntas Nacionales, editada por primera vez en Madrid en 1813, sancionada por las Cortes Doceañistas en 1812.

${ }_{11}$ M. Artola, Historia de España. La revolución liberal burguesa, p. 35.
} 
legislación es para los hombres que piensan. La urdimbre tejida finamente por esos años fue recordar que el lugar que ocupa el rey depende siempre de un convenio, de la voluntad del pueblo, en quien descansa la soberanía. La urdimbre tejida no fue para acercarse a Juan Jacobo Rousseau, sino para imaginar los antiguos bosques medievales hispanos, donde se hallan las Constituciones. El puente se abría, para inventar la nación.

\section{0: La recomposición del pacto monárquico. De la soberanía real, a la soberanía nacional}

Varios han sido los modelos de interpretación para explicar las independencias en la América Española. La historia oficial heredada del patrón liberal y patriótico del siglo XIX, puso énfasis en que las causas que desataron los movimientos insurgentes radicaron en las diferencias y conflictos entre criollos y peninsulares. Desde esta posición, el criollismo del siglo XviI fue un movimiento ideológico y cultural que le dio identidad a los reinos de América a través de la escritura de obras como La historia antigua de México de Francisco Javier Clavijero, de la recuperación del legado de Sor Juana Inés de la Cruz y de Carlos de Sigüenza y Góngora, de la producción discursiva de la oratoria sagrada que enfatizó las bondades de la tierra americana y los milagros ocurridos en agrestes cerros como el del Tepeyac: la venturosa superioridad de la virgen María de Guadalupe sobre la patrona de España, la virgen del Pilar de Zaragoza, representó uno de los símbolos edificantes para formar la conciencia americana. El criollismo, según este modelo de interpretación, dotó de diferencia, identidad, singularidad y superioridad a la América Septentrional. Este movimiento ilustrado novohispano dejó su rastro en la formación de una actitud de revaloración criolla capaz de recuperar sus territorios y riquezas de los tres reinos del mundo natural: el vegetal, el mineral y el humano. Las expediciones científicas fueron un ejemplo de la diversidad de los microcosmos de ultramar.

Dotar de conocimiento sobre el territorio, su potencial y los hombres que lo habitaron, orientó el patriotismo del siglo XviII en la Nueva España. Lo que se conoce, se le ama. Esta fórmula que sintetizó la conciencia americana fue una respuesta a las interpretaciones que desde el norte de Europa se habían elaborado sobre los reinos de ultramar. Frente a las categorías de barbarie, incivilidad o falta de razón con las que calificaron a los nativos de las colonias americanas, en especial los tratados de Raynal, William Robertson y de Cornelius de Pauw, los escritos de quienes viajaron a la América como Humboldt, o de quienes elaboraron desde el exilio una visión documentada sobre la vida natural, política y cultural, como Clavijero, representaron un nuevo horizonte hermenéutico para imaginar e inventar la América Española.

El modelo de interpretación basado en el conflicto interétnico al que hemos aludido, se valió de las bondades de la tradición cultural criolla para oponer la 
presencia "gachupina" en una dicotomía irresoluble como motor que dislocó la relación de la Nueva España con su metrópoli. La guerra de independencia se debió fundamentalmente a la lucha entre criollos (asumida su condición étnica gracias al movimiento criollista) contra los peninsulares que habían ocupado la mayoría de los cargos públicos y concentrado en sus manos la riqueza generada de la explotación agrícola, ganadera y minera.

Este modelo patriótico tuvo varias consecuencias para la interpretación general de la historia de México que conviene poner bajo análisis: su predominio en la memoria histórica oficial se debió a la historiografía patriótica heredada del siglo XIX, la cual reprodujo la idea de que la insurgencia fue un movimiento autónomo, ajustado a sus propias causas interétnicas bajo un fuerte sentimiento antiespañol. La Nueva España se concibió separada desde un inicio de su metrópoli, bajo la égida de la emancipación y carácter libertario. Este mito de la nación mexicana forjado desde sus entrañas con la recuperación de la historia gloriosa indígena del México prehispánico, oscureció el proceso de renovación político y administrativo impulsado por la corona española a través de las reformas de la casa Borbón, que pretendieron centralizar el poder, racionalizar la vida burocrática institucional y refuncionalizar la dimensión geopolítica del conjunto de los reinos que integraban a la monarquía. Proceso contradictorio que en su propio devenir histórico desencadenó varias líneas descentralizadoras que reforzaron las tendencias autonómicas de América: una de las más importantes, la encabezada por los criollos.

El mito de la nación mexicana reproducido desde los primeros discursos y oraciones cívicas que conmemoraron el grito de Dolores de septiembre de $1810,{ }^{12}$ buscó eliminar de manera intencionada la tradición española, reinventar su pasado prehispánico y separar abruptamente el proceso por el cual la propia monarquía en su conjunto —a partir de la coyuntura de crisis de 1808establecía un nuevo escenario jurídico para superar la situación de interregno. En este sentido, el 16 de septiembre de 1810 se impuso en la memoria histórica mexicana sobre el 24 de septiembre de ese mismo año. El grito del cura Hidalgo en la parroquia de Dolores fue aceptado por la visión patriótica como el inicio de la nación mexicana. El esfuerzo constitucional liberal gaditano representó entonces un pasaje de la historia que si bien no había que dejar en el olvido, tampoco debía ser tópico para celebrar la patria. ¿Qué patria? La idea de patria monárquica española quedó de esta manera desdibujada frente a un ideologizado sentimiento antiespañol y en su lugar, se impuso en el imaginario, la nación del Anáhuac. El resultado de esto, es que la forja de la nación se debió a la lucha emancipatoria encabezada por la tradición criolla novohispana desde el movimiento armado libertario de la guerra de insurgencia.

12 Virginia Guedea, Historiografía mexicana, vol. III. El surgimiento de la historiografía nacional, México, UNAM, 1997; Ernesto De la Torre Villar, La conciencia nacional y su formación. Discursos cívicos septembrinos, México, UNAM, 1988. 
Frente al modelo patriótico liberal, se formaron diversas interpretaciones sobre los orígenes, el desarrollo y la lógica de la guerra de insurgencia. Ya otros historiadores han realizado síntesis historiográficas que defineron las orientaciones y preguntas rectoras que han formulado paradigmas explicativos sobre las independencias en la América Española. Sin embargo, menciono algunos de los modelos más representativos que han circulado en México para explicar el proceso de independencia.

El modelo reactivo de John Lynch, analiza la respuesta política americana a la nueva colonización europea: según el historiador inglés, se trató de "un mecanismo de defensa puesto en movimiento por la nueva invasión española del comercio y los cargos fiscales". ${ }^{13}$ Tomando el contexto de la crisis financiera de la monarquía española y su estado de bancarrota, está la explicación de Carlos Marichal, ${ }^{14}$ quien señala que tal situación desencadenó en la primera década del siglo XIX, un cuestionamiento diversificado socialmente sobre la política administrativa de la corona.

La interpretación de historiadores como Virginia Guedea y Jaime E. Rodríguez ha reparado en que el autonomismo novohispano no pretendió la independencia de la península, sino el autogobierno de sus territorios a la vez que el reconocimiento de la soberanía en la corona española. ${ }^{15}$ A diferencia de esta perspectiva, el modelo protonacionalista — con los aportes de Ernesto de la Torre Villar, ${ }^{16}$ Carlos Herrejón $^{17}$ y David Brading ${ }^{18}$ — destaca la formación de procesos políticos y culturales que ayudaron a formar un sustrato cultural americano distinto del español, donde fue posible concebir de manera embrionaria, una nación criolla independiente a lo largo de la segunda mitad del siglo XVIII. John Tutino, desde la historia regional y social, puso énfasis en las condiciones particulares del Bajío novohispano a través del análisis de los aspectos laborales, sociales, territoriales y económicos. ${ }^{19}$.El reciente volumen de Eric van Young representó un aporte para comprender la otra rebelión desde una posición hermenéutica cultural: las causas de Hidalgo no fueron las mismas según los diferentes actores involucrados que también participaron en la insurgencia. ${ }^{20}$ Este crisol de interpretaciones sobre

13 John Lynch, Las revoluciones hispanoamericanas, 1808-1826, Barcelona, Ariel ed, 2001, p. 23.

14 Carlos Marichal, De colonia a nación. Impuestos y política en México, 1750-1860, México, El Colegio de México, 2001.

15 Virginia Guedea, En busca de un gobierno alterno. Los Guadalupes de México, México, UNAM, 1992; La independencia de México y el proceso autonomista novohispano 1808-1824, México, UNAM, Instituto Mora eds, 2001. Jaime E. Rodríguez, La independencia de la América Española, México, FCE/El Colegio de México/Fideicomiso Historia de las Américas eds, 1996, y Nosotros somos ahora los verdaderos españoles, México, El Colegio de Michoacán/Instituto Mora eds, 2009.

16 Ernesto de la Torre, La independencia mexicana 3vols., México, Sep-ochentas ed., 1989, y En torno a la formación de la conciencia mexicana en la Nueva España, México, UNAM, 1989.

17 Carlos Herrejón Peredo, Morelos. Antología documental y estudio introductorio, México, SEP ed, 1985; Hidalgo, razones de insurgencia, México, SEP ed, 1987.

18 David Brading, Orbe indiano. De la monarquía católica a la república criolla; Los orígenes del nacionalismo mexicano, México, FCE, 1998, y La Virgen de Guadalupe. Imagen y tradición, México, Taurus ed., 2002.

${ }_{19}$ John Tutino, De la insurrección a la revolución en México. Las bases sociales de la violencia agraria, 1750-1940, México, Era ed, 1990.

${ }_{20}$ Eric Van Young, La otra rebelión. La lucha por la independencia de México, México, FCE, 2000. 
las guerras de independencia analizó por una parte, los límites de la explicación patriótica y ofreció por otra, una interacción de ellos mismos para matizar la carga de los mitos nacionales forjados desde el siglo XIX. ${ }^{21}$

Me interesa, en particular, destacar el modelo de lo político que ha articulado dos vías para la comprensión de la formación de las naciones en América. Dicho modelo puso bajo crítica la explicación de la lucha étnica como motor que arrancó los procesos insurgentes e independentistas. La insurgencia no fue una reacción a la presencia y control político de los peninsulares, sino una respuesta a la crisis de soberanía de 1808. La base en la que descansa la argumentación de este modelo es la dimensión política entendida como el horizonte que ordena y da sentido a la vida comunitaria y a la acción colectiva. Se trata de comprender históricamente la esfera de lo político, de tomar en consideración la interacción de las instituciones con los acontecimientos y las tradiciones por encima del relato cronológico de la vida institucional: explicar, en suma, la formación de un horizonte temporal y espacial que da sentido y significado a la acción colectiva. Los resortes del fenómeno insurgente en su conjunto, se movieron fundamentalmente por la crisis del pacto monárquico y abrieron un mundo como posibilidad para pensar la nación.

Retomo la reflexión de Pierre Rosanvallon en torno a la dimensión de lo político: "(es) hablar del poder y de la ley, del Estado y de la nación, de la igualdad y de la justicia, de la identidad y de la diferencia, de la ciudadanía y de la civilidad, en suma, de todo aquello que constituye a la polis más allá del campo inmediato de la competencia partidaria por el ejercicio del poder, de la acción gubernamental del día a día y de la vida ordinaria de las instituciones".22

La crisis no fue, como lo ha explicado Pérez Vejo, resultado de un conflicto de identidades, sino fundamentalmente, de alcance político. Crisis de soberanía y de legitimidad: "Las guerras de independencia fueron un conflicto político, una lucha por la legitimidad del poder, y es en este contexto en el que debemos estudiarlas [...] En el origen de las guerras de independencia hay un problema político, pero no, y esta es otra precisión importante, de identidades en conflicto, sino un conflicto de soberanías". ${ }^{23}$ Se trató de una crisis del pacto monárquico español que mostró el tránsito de la soberanía real, a la soberanía nacional.

La crisis dinástica desencadenó la búsqueda por recomponer el pacto de la monarquía española. En ese contexto, como lo ha explicado Portillo Valdés, se desató la pregunta por la soberanía. Cuestión rectora que tuvo dos revoluciones:

\footnotetext{
21 Cada uno de estos modelos no forman estancos separados. Las explicaciones se han enriquecido en la complementación de líneas de investigación, en la contrastación de los casos locales y regionales, en la incorporación de mismas preguntas a realidades diferenciadas territorial y culturalmente.

22 Pierre Ronsavallon, Por una historia conceptual de lo político, México, FCE, 2003, p. 20.

23 Tomás Pérez Vejo, "El problema de la nación en las independencias americanas: una propuesta teórica”, Mexican Estudies/Estudios Mexicanos vol. 24, No. 2, California University, 2008, p. 226.
} 
la social y armada con las insurgencias en América, y la jurídica constitucional desde el recinto de las Cortes de Cádiz, con la participación de peninsulares y americanos. ${ }^{24}$ En este sentido para el caso novohispano, la comprensión histórica de septiembre de 1810 cambia radicalmente, pues se trató de la confluencia de estas dos vías para la comprensión de la disolución del pacto: la vía insurgente del 16 de septiembre y la vía de la representación en Cádiz del 24 de septiembre. Ambas buscaron conservar los dominios del rey y defenderlos del invasor francés; pretendieron en sus inicios recomponer el pacto social; expresaron paradójicamente- su carácter revolucionario en la dirección de defensa de la soberanía española y en la conservación de los distintos territorios al monarca. Ambas participaron en la esfera de acontecimientos en cascada que definieron la disolución del pacto; significaron un momento histórico extraordinario en el que la política fue la dimensión de sentido cultural para reorientar el curso de la historia de la monarquía española.

iViva la América! iViva la religión católica! iViva Nuestra Señora de Guadalupe! iMuera el mal gobierno! iViva el rey!, fue la fórmula que pasó a la historia como el grito de Dolores. El cura Hidalgo tomó tres imágenes para su lucha: la Virgen de Guadalupe, el águila mexicana y el retrato de Fernando VII. A través de la lectura de la Gaceta de México, conoció la noticia de los sucesos en la península con la presencia militar francesa. América era parte de la monarquía. Si Napoleón había ya ocupado la península, lo que seguía en su mira era ocupar la América española. Esta fue una de las razones expresadas por el cura de la parroquia de Dolores para iniciar la defensa y conservación de los dominios del monarca. Por su parte, la declaración de los diputados americanos y peninsulares reunidos en la Isla de León en su segundo día de sesiones fue contundente: rechazaron, de manera unánime, cualquier intento por parte del emperador francés de imponer su soberanía, calificaron de nulas las abdicaciones de la corona española y ofrecieron su reconocimiento a Fernando vII como legítimo monarca.

Las dos vías expuestas para la comprensión histórica de la disolución del pacto, cada una en su cauce, participaron en la reformulación de la soberanía. Las revoluciones insurgente y constitucional, derivaron en el tránsito de la soberanía real a la soberanía nacional. Ambas, en su pretensión por conservar a la monarquía, fueron profundamente revolucionarias.

\section{2: ¿Qué nación, España o América?}

El 19 de marzo de 1812 se proclamó la Constitución Política de la Monarquía Española. Como lo ha expuesto Manuel Chust, el primer ejercicio constitucional de Hispanoamérica representó un drama para recomponer el Estado sin cambiar la forma de gobierno. Había sido la monarquía, y la monarquía debería seguir rigiendo la vida de sus habitantes. La monarquía representaba la experiencia de

24 J. Rodríguez, "Dos revoluciones” en Nosotros somos ahora los verdaderos españoles, pp. 199-294. 
gobierno que había garantizado unidad y permanencia del pacto social. Siguiendo a Chust Calero, se trató de hacer compatible Corona y Constitución. ${ }^{25}$ Desde el Diario de Sesiones de las Cortes se plantearon distintas argumentaciones para volver compatible, constitucionalmente, lo que la tradición jurídica reconocida en la concepción monista de la soberanía, por siglos había establecido.

La Constitución Política de la Monarquía Española es ubicada dentro del conjunto de constituciones de carácter revolucionario, con elementos comunes y divergentes respecto a sus antecesoras norteamericana y francesa; y con contenidos de gran influjo en las constituciones consecuentes como la de Portugal de 1822 y las elaboradas en América como la mexicana de 1824. Miguel Artola, al explicar su carácter revolucionario, sostiene que "ninguna retórica podía ocultar el carácter revolucionario del texto constitucional, del mismo modo que no cabía ignorar las consecuencias que se seguirían de su publicación. El sistema político sancionado en Cádiz no oculta la presencia de los postulados liberales: derchos del hombre, soberanía nacional y división de poderes". ${ }^{26}$

El título tercero de la Constitución de 1812 señalaba que "la soberanía reside esencialmente en la nación y por lo mismo pertenece a ésta exclusivamente el derecho de establecer sus leyes fundamentales". ${ }^{27}$ Se trataba de formar un constructo bajo el nombre nación, con división de poderes, imaginado a partir del conjunto heterogéneo de territorios tanto de América como de España, con habitantes llamados ciudadanos españoles y con nuevas formas de ejercer la representación territorial. La nación era la soberana, no ya el monarca. Como nación soberana tenía la facultad de elegir su forma de gobierno y las leyes que la ordenaran. El doceañismo gaditano representó dos innovaciones con respecto a la tradición legal castellana: el paso de la soberanía real a la soberanía nacional y el espacio para la representación de los reinos de ultramar. Como sostiene Jaime E. Rodríguez: "Ninguna otra metrópoli europea otorgaba a sus territorios ultramarinos una representación similar. El parlamento inglés, considerado por lo general como el más avanzado en el mundo, nunca consideró otorgar a sus colonias en Norteamérica más que una representación virtual" ${ }^{28}$ La Constitución de 1812 eliminaba para América la condición de colonia y le otorgaba, por contraparte, la misma estima jurídica que España. No fue por tanto, la nación española integrada por una metrópoli y el conjunto de satélites, sino que se identificaba, grosso modo, que esa nación española estaba compuesta por ambos hemisferios, donde habitaban ciudadanos españoles, ocupando territorios diversificados con posibilidad de representación en Cortes, Diputaciones y Ayuntamientos. Una nación libre e independiente de cualquier

\footnotetext{
25 Manuel Chust e Ivana Frásquet, "Soberanía hispana, soberanía mexicana. México: 1808-1824", en Manuel Chust (coord.), Doceañismos, constituciones e independencias. La Constitución de 1812 y América, Madrid, MAPFRE ed, 2006, pp. 169-236.

26 M. Artola, Historia de España. La burguesía revolucionaria, p. 42.

27 Constitución Política de la Monarquía Española, 19 de marzo de 1812.

28 J. Rodríguez, "Dos revoluciones", Nosotros somos ahora los verdaderos españoles, pp. 199-294.
} 
otra nación; independencia que cerraba toda posibilidad de ser patrimonio familiar o personal, ${ }^{29}$ fuera de Napoleón o de la misma dinastía española.

La gran revolución de nociones jurídicas y políticas en torno a la summa potestas, fue que ésta dejó de ser el supremo poder encabezado unipersonalmente. La continuidad es que conservó su carácter unitario e indivisible. Por encima de la nación, el derecho positivo a través de la Constitución. La novedad no radicó, por tanto, en la forma de gobierno, sino en cómo asegurar que esa forma de gobierno monárquica permaneciera en el concierto internacional de los estados europeos a través de la traslación de la soberanía real en la soberanía nacional.

En tal sentido, el pacto tuvo que recomponerse: el ciudadano español y no el vasallo de la corona, debía rendir obediencia y lealtad a la nación. Con la Constitución liberal de 1812, el pacto traslatii perdió la vigencia que como nunca antes había cobrado en 1808. Si bien entre 1808 y 1810 la soberanía no había regresado al pueblo, sino que se encontraba en depósito mientras el rey regresara a ocupar el trono, desde 1812 de manera formal se eliminó el riesgo por el que ya se había pasado: la soberanía no regresaría al pueblo, porque no habría la posibilidad de que, con la ausencia del rey o impedido para ejercer el poder —en su carácter de soberano- regresara al pueblo. No había posibilidad de regreso porque ahora la soberanía residía en la nación. En su ausencia, la Constitución previó "la creación de una Regencia nombrada por las Cortes" ${ }^{30}$ El liberalismo revolucionario gaditano habló de soberanía nacional, no de soberanía popular.

Bajo este nuevo contexto jurídico, ¿cómo defender la soberanía de la nación? El pacto se reconfiguraba: la nación estaba obligada a conservar y proteger con la ley, la libertad civil, la propiedad y los derechos legítimos de los individuos que la integran (artículo 4o). Los ciudadanos serían llamados por la ley a defenderla cuando se hallare amenazada. La virtud de la monarquía constitucional no fue más el honor, sino el amor a la patria establecido como obligación en el artículo 6o. Se defiende a la nación, se ama a la patria. El pacto liberal gaditano comprendía una mutación en la lealtad del gobernado: no al monarca sino, en primera instancia, a la Constitución; en segunda, respeto y obediencia a las autoridades.

Bajo un contexto de guerra, se definió jurídicamente la nación española y la soberanía nacional. Sin embargo, los artículos que armaban el territorio de la nación española, fueron preámbulo para imaginar la polisemia de nación, la dimensión política de la nación, la identidad de la nación. Mónica Quijada se preguntó “¿qué nación? ¿desde cuándo hay nación?”. ${ }^{31}$

29 Constitución Política de la Monarquía Española, artículo 2o.

30 M. Artola, Historia de España. La burguesía revolucionaria, p. 45.

31 Mónica Quijada, “¿Qué nación? Dinámicas y dicotomías de la nación en el imaginario hispanoamericano", en Antonio Annino y François-Xavier Guerra (coords.), Inventando la nación. Iberoamérica. Siglo XIX, México, FCE, 2003, pp. 287-315. 
Para el caso novohispano en el año de 1812 las preguntas planteadas por la historiadora cobran toda su potencia. El artículo décimo indicaba el ámbito territorial de lo que se concebía territorialmente por América Septentrional: la Nueva España, la Nueva Galicia, la Península de Yucatán, Guatemala, las Provincias Internas de Oriente, las Provincias Internas de Occidente, la isla de Cuba con las dos Floridas, la parte española de la isla de Santo Domingo y la isla de Puerto Rico. La división así establecida por los diputados en Cádiz de la América Septentrional con respecto a la América Meridional se colocaba por encima de todo intento criollista novohispano o rioplatense por imaginar su predominio sobre el resto de la América. El predominio lo tenía ahora la Constitución de nación que indicaba cuáles de los territorios la comprendían.

En 1808 se dio la guerra de independencia y se abrió la posibilidad, dos años después, para organizar la nación. Independencia de la monarquía española con respecto a la invasión francesa. En 1812 se decretaba constitucionalmente a la nación española, pero en la Nueva España iniciaban los intentos independentistas respecto a la Vieja España así como los primeros planteamientos para configurar jurídicamente a la nación americana.

Dos acciones políticas y militares definieron 1808 y 1812: la acción de las juntas provinciales y la Junta Central, así como el levantamiento armado de Hidalgo por lo que respecta al Bajío novohispano, mostraron una política de defensa de la monarquía y de búsqueda de independencia de Francia; por los mismos cauces, la Nueva España en 1812 — cuando era reconocida como parte de la América Septentrional, en el hemisferio de América, en la nación española — se valía de los mismos mecanismos para imaginar la nación: el político y el militar. El desarrollo de la guerra de la insurgencia buscó estrategias para empezar a deslindarse de la península ibérica y de la nación española. El rey, además de cautivo, estaba a más de dos mil leguas de América. Esta condición de lejanía física fue uno de los más severos cuestionamientos que se hicieron por distintos actores involucrados en la guerra que debilitó en el imaginario aquel patriotismo inusitado de 1808. Como se ha explicado, las primeras manifestaciones discursivas de la guerra de independencia fueron directamente contra Napoleón Bonaparte:

El objeto de nuestra empresa no es otro que la expulsión de los europeos, facción en que convierte la seguridad de Nuestra Religión Católica, la guarda de estos preciosos dominios a nuestro soberano Fernando VII y la libertad política de nuestra nación en que estriba el goce de nuestros derechos usurpados por ellos [...] Quinientos emisarios del inicuo Bonaparte estaban introducidos en nuestro continente y repartidos en todas sus provincias de que había resultado ya el venenoso fruto de sus diabólicas fatigas con la convocación de más de diez mil europeos para hacernos infelices, víctimas de las infamias, destruir nuestra cristiana religión, acabar con la dependencia de nuestro católico monarca, propagar la esclavitud. ${ }^{32}$

32 Archivo Histórico del Estado de Zacatecas, Fondo Poder Judicial, Serie Criminal, Causa formada al subdelegado en Nieves, Juan de Aguilar por insurgente, febrero 17 de 1811. 
La virgen de Guadalupe amparaba bajo su patrocinio el éxito del movimiento. Las fórmulas de exclamación continuaron con el inicial iViva la América! iViva nuestra Santa Religión Católica! iMuera el mal gobierno! iViva el rey!, pero ahora incluyeron el iViva la leal y noble Nación Americana! Este elemento marcó una primera ruptura de gran simbolismo en el desarrollo del movimiento insurgente. Fue pronunciado al tiempo en que las Cortes de Cádiz daban cuerpo a la nación española. La fórmula discursiva mutó: nación americana en la defensa del monarca español y de la religión católica.

Con la derrota que sufrió el cura Hidalgo y sus acompañantes en Puente de Calderón en enero de 1811, los motivos de la insurgencia tomaron otros tintes. Ignacio López Rayón probó varios intentos por establecer una Junta Nacional Americana. Sus esfuerzos se concretaron en agosto en Zitácuaro, lugar en el que se reunieron José María Cos, Sixto Verduzco y José María Liceaga para proponer un Congreso que tomara bajo su rectoría no sólo el movimiento insurgente heredado de su primer líder, sino la dirección que debería tomar la América Septentrional. La voz independencia dejó atrás cualquier intento autonomista: "no hacemos guerra contra el Rey [...] nuestros planes en efecto, son de independencia, pero creemos que no nos ha de dañar el nombre de Fernando, que en suma viene a ser un ente de razón". 33

Desde el periódico insurgente El Ilustrador Americano, José María Cos radicalizó el discurso respecto a la presencia española y a la existencia de una nación americana legitimada en sus causas y en sus objetivos. Es la nación americana en guerra —organizada política, jurídica y militarmente- la que se enfrenta con el opresor en una lucha legítima por defender sus derechos:

... a pesar de las mentiras con que procuran alucinarlo algunos gachupines perversos y tontos, debe saber a la hora de esta, que no está peleando con una gavilla de ladrones, sino con la nación levantada en masa, que reclama y sostiene sus derechos con la espada, que tiene ya un gobierno organizado, establecidos los fundamentos de su Constitución y tomadas sus providencias para llevar al cabo sus justas pretensiones. ${ }^{34}$

A partir de este evento político en la Nueva España, de transitar de la soberanía real a la soberanía nacional en la segunda etapa de la guerra de insurgencia, los españoles fueron considerados europeos, pertenecientes a otro contiente, regidos por sus usos y costumbres, por su propia Constitución. El discurso de exaltación

\footnotetext{
33 "La Junta Independiente de Zitácuaro hace explicaciones al Sr. Morelos sobre el motivo por el que aun se proclama a Fernando viı", Juan Hernández y Dávalos, Historia de la guerra de Independencia de México 6 vols., I, México, Instituto Nacional de Estudios Históricos de la Revolución Mexicana, 1985, p. 874.

34 "El Ilustrador Americano No. 2. Comunicación al virrey, remitiéndole el plan de paz y de guerra de 16 de marzo. Manifiesto a la Nación. Refutación a la Gaceta", Juan Hernández y Dávalos, Historia de la guerra, IV, p. 189.
} 
del americano y de vituperio al español fue adquiriendo mayor divulgación y fuerza a partir de 1812 con el correr de la guerra de insurgencia. En este contexto el problema político se volvió un problema jurídico con muchas aristas: se pretendía en territorio americano, por parte de los insurgentes novohispanos, formar una nación separada de la española. Empero, ya se había constituido y proclamado la nación española desde el recinto legislativo en el Puerto de Cádiz por los diputados americanos y los peninsulares apenas unos cuantos meses antes. A esto se agrega que la nación americana imaginada por los insurgentes desde Zitácuaro, seguía manteniendo vigente su relación con el monarca español. A pesar de este enredo por formar qué nación, un elemento rector tuvieron en común los gaditanos doceañistas y los insurgentes en Zitácuaro: la soberanía no debía descansar más en el monarca sino, esencialmente, en la nación. ¿Qué nación?

En el Manifiesto a la nación Americana, José María Cos dirigió su pluma a los españoles a quienes aclaraba cuál era su patria: "sois más americanos que europeos"; el cura abría su reflexión sobre la idea de patria: el hecho de apenas nacer en un territorio, no hace el sentido global de patria; éste lo da el transcurrir de la mayor parte de la vida en un territorio, el relacionarse con los usos y costumbres [de América]; el hacerse natural a estos climas; el haber establecido relaciones sociales y generar sucesión. En pocas palabras, para el cura de San Cosme de la provincia de Zacatecas, la patria consistía en "crear raíces profundas" ${ }^{35} \mathrm{El}$ doctor Cos buscó formar una imagen de patria como la generación de un epicentro: un lugar central vivido con el correr de los años, capaz de procrear relaciones sociales e intereses económicos; capaz de participar de las costumbres locales, en suma, vivir la patria y no sólo nacer en ella. España quedaba muy lejos en este horizonte vital y cultural, a más de dos mil leguas de distancia.

En junio de 1812, José María Cos publicó en el número cinco de El Ilustrador Americano, el "Plan de paz y de Guerra". Los principios en los que se sustentaba se basaban en la inmediata tradición de Cádiz, pero anteponiendo los obstáculos necesarios para alejarse lo suficientemente de ella. Así como en aquella carta magna, fue declarado por los insurgentes en la Nueva España que "la soberanía reside en la masa de la nación"; en su punto siguiente declaraba lo mismo que Cádiz había contemplado en el título de la nación española: la integración territorial de la monarquía española por América y España, no obstante añadía: "sujetas al rey, pero iguales entre sí y sin dependencia o subordinación de una respecto a la otra". La diferencia sustantiva con respecto a la Constitución gaditana de 1812 quedó en su tercer punto: "Más derecho tiene la América fiel para convocar Cortes y llamar representantes de los pocos patriotas de España contagiada de infidencia, que España llamar de América diputados, por medio de los cuales nunca podemos estar dignamente representados". ${ }^{36}$ No podía ser

5 El Ilustrador Americano No. 2, p. 208.

36 El Ilustrador Americano No. 2, p. 208. 
más clara la oposición a través de evidentes juicios de valor: América fiel, España plagada de infidentes.

José María Cos habló de representación en un tono crítico con respecto a las recientes celebradas Cortes de Cádiz. Tendría más valor, suponía, unas Cortes en América que convocaran a algunos españoles patriotas. En América se podía garantizar la cantidad suficiente de diputados, cuestión que no se había logrado en el puerto español. El hecho de que la soberanía residiera en la nación, y que en América se celebrara su Congreso, implicaba no sólo un viraje territorial, sino la ubicación en territorio de América, donde se darían cita los representantes de la nación quienes serían el principal garante de la soberanía nacional. Lejos del usurpador francés, pero también de la dinastía española. En tal sentido, la separación territorial no era más que una expresión de la separación política: "Ausente el soberano, ningún derecho tienen los habitantes de la península para apropiarse la suprema potestad y representarlo en estos dominios". ${ }^{37}$ Del uso de la representación territorial de la monarquía española, expresada en el segundo punto de los “Tratados de paz y Guerra”, a la nación americana se le otorgaba el derecho de conspirar para impedir someterse a la monarquía española calificada, en el sexto punto, con el mote de "imperio arbitrario". Nación americana, legítima, en el ejercicio de su derecho a enfrentarse a la arbitrariedad del imperio español. El rey estaba a salvo. Las acciones relativas a cualquier intento de conspiración en América no serían calificadas como delito de lesa majestad, sino de patriotismo. Las piezas se acomodaban desde la perspectiva de este grupo de insurgentes: el rey era la majestad (no el soberano); los españoles eran los gachupines y la nación, congregada en este nuevo Congreso nacional americano, detentaba la soberanía. En el contexto de los sucesos recientes de 1808, la nación americana debía ocuparse de su propia seguridad, y no podía ser de otra manera, más que poniendo "en ejecución el derecho que tiene de guardar estos dominios a su legítimo soberano por sí misma, sin intervención de gente europea”. ${ }^{38}$ En este sentido, lo que para los opositores a la insurgencia, el movimiento fue calificado como una serie de asesinatos, robos, sangre y violencia, sus defensores y líderes lo concibieron como su derecho a conservar los dominios del monarca y su derecho a dar plataforma jurídica a la nación americana.

La posterior publicación de los Sentimientos de la Nación de José María Morelos en septiembre de 1813, terminó por deslindar a la nación americana de la monarquía española. Desde su primer título, se declaraba la total independencia de América respecto a cualquier otra nación o monarquía. A diferencia de la Constitución de Cádiz y de los "Tratados de paz y guerra", la soberanía descansaba en el pueblo y no en la nación. La soberanía es inmediata al pueblo y como pueblo soberano, hace uso de su poder depositándola en sus representantes divididos en los tres poderes. Nación americana, soberanía popular, división de poderes,

37 El Ilustrador Americano No. 2, p. 208.

38 El Ilustrador Americano No. 2, p. 222. 
independencia de España, constituyeron los vectores políticos de los insurgentes entre 1812 y 1813. Los extranjeros sólo podrían ser recibidos en tierra americana en calidad de artesanos e instructores, y no para ocupar ningún cargo público. No sería libre la América hasta en tanto no se expulsare de esta tierra todo rastro del tirano. Con ello, se apartaba abruptamente de los "Tratados de paz y guerra" que le guardaban un lugar a los representantes de España en el Congreso americano.

En ambas experiencias revolucionarias e independentistas — la de Cádiz en 1812 respecto a Francia y la de la Junta Americana respecto a España- la fórmula jurídica representó un segundo momento en la conquista del poder. El primero había sido la acción militar, el levantamiento popular, la puesta en armas de los distintos sectores sociales; sin embargo eso no bastaba: en ambos ensayos revolucionarios el paso a seguir fue la organización jurídica de la nación: la construcción y el arribo de una nueva legitimidad.

\section{Nación, revolución y federalismo}

Las dos vías para la comprensión de la disolución del antiguo pacto monárquico tuvieron en común el establecimiento del liberalismo revolucionario. Durante el primer periodo de vigencia de la Constitución de Cádiz en las ciudades, villas y pueblos de la Nueva España se leyó desde los púlpitos el documento constitucional, se mandó que las plazas de armas a partir de entonces llevaran el nombre de "Plaza de la Constitución" donde debía ser colocada una lápida en honor a los primeros padres de la patria: aquellos que defendieron la península ibérica de la presencia militar francesa. La nación americana de los insurgentes convivía con la vigencia de la constitución de Cádiz que prolongaba en el imaginario el heroismo de aquellos que defendieron la patria monárquica católica.

Fue el tiempo en que se establecieron las primeras diputaciones provinciales de acuerdo con lo prescrito por la Constitución sobre los distintos niveles de representación territorial. Desde 1813 se instalaron en suelo novohispano las diputaciones de las Provincias Internas de Occidente, las Provincias Internas de Oriente, Nueva Galicia, San Luis Potosí, Nueva España, Yucatán y Guatemala. ${ }^{39}$ De la misma manera, en este periodo gaditano se establecieron los primeros ayuntamientos constitucionales, cerca de 900 en 1814. Antonio Annino estudió el proceso por el cual el constitucionalismo gaditano significó una revolución en el nivel municipal, al dotar a los pueblos de su derecho a la representación a través de la instalación de ayuntamientos constitucionales. Para Annino la revolución municipal gaditana expresó con toda su potencia no un liberalismo exclusivo de la clase política en el ejercicio del poder, sino un liberalismo popular manifestado en las demandas de comunidades, vecinos y pueblos por contar con este organismo de representación político-territorial. ${ }^{40}$

39 Nettie Lee Benson, La diputación provincial y el federalismo mexicano, México, El Colegio de México, 1992.

40 Antonio Annino, "Ciudadanía versus gobernabilidad republicana en México. Los orígenes de un 
Es decir, se trató de un liberalismo popular condicionado desde la Constitución de 1812 la cual fijó el criterio del número de habitantes para instalar ayuntamiento. Así, como lo demostraron Antonio Annino y Alicia Hernández Chávez, los 896 ayuntamientos constitucionales en el primer periodo gaditano, rebasó las tres decenas de cabildos existentes en el territorio novohispano. Su presencia significó una novedosa plataforma política y territorial en el nivel municipal.

Alicia Hernández atribuye la inaudita proliferación de los ayuntamientos a la tradición comunitaria de los pueblos en la Nueva España que poseían en su historia la costumbre de las formas de autogobierno. Justo por el criterio poblacional que exigía la Constitución para el establecimiento de ayuntamiento, es que representó un mecanismo para contener el desplazamiento y movilidad característicos del movimiento insurgente: "como los insurgentes eran vecinos y naturales de la región, su ausencia sería motivo para que un pueblo quedara sujeto a otra alcaldía. En consecuencia, el tener que reunir y registrar a los 1 000 residentes, debió ser un poderoso mecanismo de pacificación que indujo el retorno de los insurgentes a sus pueblos". ${ }^{41}$ La conclusión a la que llega es central: el antiguo orden que había fomentado la diferencia étnica a través de estamentos y corporaciones, con el constitucionalismo de 1812 empezó a fracturarse al quedar integrados en los ayuntamientos, miembros de distintas ascendencias étnicas: "la gran novedad fue el nacimiento del ayuntamiento interétnico". ${ }^{42}$

En el segundo periodo gaditano que inició en 1820, el número de diputaciones provinciales se multiplicó. El caso de Oaxaca es ejemplar para la exigencia de dicho organismo, pues contaba con una distancia de 108 leguas de la capital, 931 municipalidades, 117 parroquias y 510,000 habitantes. Zacatecas, con menor población y tan sólo con cuatro decenas de municipalidades, exigía su propia diputación porque no veían representados sus intereses políticos y económicos tanto en el organismo provincial de Nueva Galicia, donde perteneció entre 1813 y 1814, como en el de San Luis Potosí. Zacatecas puso énfasis en la solución gaditana de instalar diputación en los territorios que conformaban las intendencias, de tal manera que en 1822 el virreinato quedó dividido en 18 diputaciones y un año después aumentaron a 23. El federalismo, desde la administración provincial y siguiendo los decretos gaditanos, quedaba asentado en el territorio mexicano.

Vicente Rocafuerte compartía la idea de que la nueva realidad de México, después de la insurgencia y una vez consumada la independencia en septiembre

dilema" en Hilda Sábato (coord.), Ciudadanía política y formación de las naciones. Perspectivas históricas de América Latina, México, FCE/El Colegio de México/Fideicomiso Historia de las Américas, 1999, pp. 62-93.

${ }_{41}$ Alicia Hernández, La tradición republicana del buen gobierno, México, FCE/El Colegio de México/ Fideicomiso Historia de las Américas, 1993, pp. 24-25.

42 A. Hernández, La tradición republicana del buen gobierno, p. 25. 
de 1821, abría la posibilidad para que sus hombres imaginaran qué nación: ¿república, monarquía, aristocracia? Qué nación cuando habían pasado por la revolución constitucional de 1812, por la definición de la nación española y por el discurso insurgente que también definía a la nación americana. España se había resuelto por la monarquía constitucional; México separado de España y declarado independiente de la antigua metrópoli, seguía vinculado a través de la reciente tradición constitucional que había abierto la puerta a los liberalismos en plural.

El primer imperio del Anáhuac con Agustín de Iturbide al frente no pudo contener la fuerza del liberalismo gaditano. En síntesis, la diputaciones provinciales pusieron en jaque cualquier intento del emperador de atribuirse facultades soberanas. Ciudadanía, representación, soberanía nacional, fueron las nuevas voces jurídicas que había calado hondo en las comunidades rurales, en las cabezas de partido, en las capitales de provincia.

Una de las más importantes transformaciones del liberalismo gaditano, fue la lectura e interpretación que hicieron comunidades y pueblos del texto constitucional de 1812. Lejos de afirmar que el debate jurídico y legislativo se centró de manera exclusiva en la clase política, los dos periodos de vigencia de la carta gaditana y el primer periodo de la república mexicana (1824-1835), muestran la gran difusión que tuvo entre comunidades y pueblos la Constitución y decretos de Cádiz. Una característica muy significativa de la revolución liberal popular fue que los pueblos y comunidades, en su condición de vecinos y apegados a su tradición cívica —que enmarcaba los valores consuetudinarios como la solidaridad, el servicio a la comunidad, el honor y la virtud patriótica, la procuración del bien común- lucharon por establecer su ayuntamiento no por la vía de las armas, sino por la vía legal. Desde su tradición cívica, demandaron la defensa de sus derechos civiles. Esto implicó, por una parte, que conocieron los títulos y artículos tanto de la Constitución de Cádiz, como de las constituciones federal y estatal de la república. Por otra, les permitió interactuar con las instituciones republicanas, en particular con el poder legislativo, para integrar la voz de su comunidad a un entramado constitucional, primero monárquico y después, republicano federal.

Los recientes aportes de la historiografía sobre el tema en torno al conocimiento, difusión y arraigo del constitucionalismo gaditano, han mostrado la gran adaptabilidad que tuvo Cádiz para la recomposición administrativa y territorial en el tránsito del virreinato a la nación mexicana. En particular, la exigencia de pueblos y comunidades porque las instancias legislativas locales autorizaran la instalación de su ayuntamiento, obliga a los estudiosos a entender los motivos, las circunstancias políticas, étnicas y culturales, así como los conflictos en el proceso del reforzamiento municipalista en este periodo de tránsito. 
En general, los estudios de caso coinciden en varios elementos de innovación en la reestructura de relaciones locales y regionales de acuerdo a los diferentes contextos regionales:

a) El cambio en el tipo de relación entre los indígenas con las instituciones de gobierno y en las formas de ejercer su propio gobierno

b) El conocimiento que no sólo los juzgados, sino las comunidades y pueblos tuvieron de la Constitución, lo que hizo que a través de la recuperación de determinados títulos o artículos del código, descansaran sus demandas de representación territorial. Peter Guardino lo analizó para el caso de las comunidades indígenas de Oaxaca, donde se leyó y atendió por ejemplo, el artículo 18 que establecía: "no podrá haber en el Estado distinciones, autoridad ni poder hereditario", lo que contuvo las pretensiones de defender antiguas razones de privilegio basadas en la herencia. ${ }^{43}$

c) La innovación de los procedimientos para hacer las elecciones; la importancia y significado que antes tuvieron los ancianos y los principales fue sustituida por el criterio de edad para participar en los procesos electorales. Los antiguos usos y costumbres asociados a un proceso gradual en el paso de un cargo a otro por parte de los funcionarios, quedaron eliminados en la constitución estatal; con la transformación de las prácticas electorales, se fue configurando un nuevo sistema de legitimidad política en el cual se innovó la manera en que los actores involucrados en dichos procesos, lo hicieron en calidad de ciudadanos. ${ }^{44}$

d) El papel que tuvieron los ayuntamientos durante 1820 y 1821 de contención del movimiento armado insurgente a la vez que de rechazo a contribuir con gastos destinados a las milicias para su mantenimiento.

e) La convergencia en este órgano de representación municipal, de distintos grupos sociales y étnicos se hizo cada vez más evidente con el crecimiento demográfico donde, en una propiedad, hacienda o rancho, se fueron integrando indios, peones, vaqueros, arrendatarios ${ }^{45}$ dando pie, como lo explicó Alicia Hernández, al ayuntamiento interétnico.

f) La transformación geopolítica de la jerarquía territorial, a través del impulso municipal en la que antiguas cabeceras de partido perdieron control y predominio sobre comunidades cercanas al contar éstas con su propio órgano de representación. ${ }^{46}$

g) La consideración de los vecinos de que con la instalación de su ayuntamiento,

43 Peter Guardino, "El nombre conocido de República. Municipios en Oaxaca. De Cádiz a la primera república federal" en Juan Ortiz y José Antonio Serrano (coords.), Ayuntamientos y liberalismo gaditano en México, El Colegio de Michoacán/Universidad Veracruzana eds, 2007, p. 225.

${ }_{44}$ Michael T. Ducey, "Elecciones, constituciones y ayuntamientos. La participación popular en las elecciones de la tierra caliente veracruzana, 1813-1835", en J. Ortiz y J. A. Serrano, Ayuntamientos y liberalismo gaditano en México, p. 176.

45 Arturo Güemes Pineda, "La emergencia de los ayuntamientos constitucionales gaditanos y la sobrevivencia de los cabildos mayas yucatecos, 1812-1824", en J. Ortiz y J. A. Serrano, Ayuntamientos y liberalismo gaditano en México, p. 102.

46 José A. Serrano, Jerarquía territorial y transición política. Guanajuato: 1790-1835, México, El Colegio de Michoacán/Instituto Mora eds., 2001. 
accedían a un nuevo estatus político en relación con poderes los unipersonales como el representado por los hacendados. Fueron los casos de instalación de ayuntamiento y régimen municipal en el interior de propiedades privadas como las haciendas.

h) La utilización del lenguaje constitucional en el imaginario de comunidades y pueblos que hablaron de derechos y obligaciones en su calidad de ciudadano. Resulta significativa la declaración de los vecinos de Valparaíso en Zacatecas, en su nueva condición de ciudadanos de la república, porque se trató de una interpretación local de lo que en la década de 1820, se entendió por federalismo: "Y si nosotros, lo mismo que todo ciudadano, contribuimos a sostener la hacienda pública, si estamos preparados a defender con las armas los derechos de la nación, y si cumplimos como el que más con todos los deberes que nos impone el estado a que nos gloriamos pertenecer, ¿̇por qué se nos ha de privar de los beneficios que los demás disfrutan?". ${ }^{47}$

i) La categoría de vecino ayudó a contener la introducción de la noción de individuo. Como lo han explicado varios historiadores, la categoría de vecindad evitó la prolongación de la incertidumbre por parte de los sujetos que transitaban del orden corporativo al constitucional, es decir, de su paso de súbditos de la corona, a ciudadanos de la nación. ${ }^{48}$

Estos elementos novedosos estudiados a partir de casos concretos, dan cuenta de que una de las más significativas transformaciones del liberalismo revolucionario estuvo en el nivel municipal a partir de la proliferación de ayuntamientos. Desde la plataforma constitucional, fue que el liberalismo gaditano alcanzó a configurar el federalismo mexicano en los niveles estatal y municipal. Nettie Lee Benson lo explicó en su clásico en la década de 1950 con el análisis de las diputaciones provinciales; no obstante, siguió prevaleciendo en el imaginario de nuestra historia nacional, que la nación mexicana había sido fruto exclusivo del movimiento de insurgencia. La Constitución de 1812 no tuvo como propósito formar nuevas naciones en América, separadas de la península. Recordemos: su propósito fue dar viabilidad jurídica a la monarquía española en un contexto de crisis de soberanía. Las nuevas nociones jurídicas como soberanía nacional, división de poderes, monocameralismo, ciudadanía y representación, incubaron disímiles procesos históricos en los diferentes territorios que conformaron la monarquía española y que devinieron en la tradición republicana liberal.

En sus sesiones generales y extraordinarias, los diputados americanos y peninsulares durante 1810 y 1811 , tensaron el debate constitucional entre la

\footnotetext{
47 Mariana Terán Fuentes, "Soberanía, ciudadanía y representación en la experiencia confederal. Zacatecas, 1823-1835" en Alicia Hernández y Mariana Terán (coords.), Federalismo, ciudadanía y representación en Zacatecas, Zacatecas, Universidad Autónoma de Zacatecas/CONACYT eds., 2010, pp. 187-244. 48 Marta Irurozqui, "De cómo el vecino hizo al ciudadano en Charcas y de cómo el ciudadano conservó al vecino en Bolivia, 1809-1830” en Jaime E. Rodríguez (ed.), Revolución, independencia y las nuevas naciones en América, Madrid, MAPFRE, 2005, pp. 451-484.
} 
posición de reforzar algunos de los elementos tradicionales de la monarquía absoluta como mantener antiguos privilegios, o emprender innovaciones como la de consolidar el movimiento autonomista. En este importante enfrentamiento de posiciones e ideas, el peligro era latente: desatar cualquier pretensión federalizante. El federalismo era asociado con anarquía, con ausencia de un tronco que diera unidad a la diversidad territorial, con ausencia de nación. Como Manuel Chust lo ha destacado:

[Las] propuestas autonomistas americanas significaban integrar en calidad de territorios en igualdad jurídica a las antiguas colonias dentro de un Estado-nacional con parámetros plurinacionales. Y desde luego dejaba planteado el problema: ¿cómo articular este estado plurinacional bajo premisas monárquicas? El primer parlamentarismo español nace con pretensiones de centralidad, de unicidad que no son gratuitas [...] Los liberales peninsulares se tienen que enfrentar a un insospechado problema americano, tienen que construir un Estado nacional con parámetros de EstadoNación-Imperio. Tenían, verdaderamente, un problema teórico, ideológico, práctico y táctico. Urgía recurrir a la experiencia. ¿Qué tal si mentamos federalismo? ${ }^{49}$

Ese riesgo latente cobró su expresión histórica con la formación de las nuevas naciones en América y la opción republicana. Para el caso mexicano, la revolución liberal constitucional devino, sin proponérselo, en la formación de la república federal.

\section{La divulgación de las grandes verdades. El uso de los catecismos políticos}

Pregunta: Decid niño, ¿̇cómo os llamáis?

Respuesta: Español.

P: ¿Qué quiere decir español?

R: Hombre de bien.

P: ¿Cuántas y cuáles son sus obligaciones?

R: Tres. Ser cristiano, católico, apostólico y romano; defender su religión, su patria y su rey y morir antes de ser vencido.

P: ¿Quién es nuestro rey?

R: Fernando VII.

P: ¿Con qué amor debe ser obedecido?

R: Con el amor que lo han hecho acreedor sus virtudes y desgracias.

P: ¿Quién es el enemigo de nuestra felicidad?

R: El emperador de los franceses.

P: ¿Y quién es este hombre?

49 Manuel Chust, La cuestión nacional americana en las Cortes de Cádiz, Valencia, Centro Francisco Tomás y Valiente/ Fundación Instituto Historia Social/UNAM, 1999, p. 57. 
R: Un nuevo señor infinitamente malo y codicioso, principio de todos los males y fin de todos los bienes; es el compendio y depósito de todos los vicios y maldades. ${ }^{50}$

En 1808 se reprodujo este catecismo político-civil "muy útil" como se aclara en sus datos editoriales, para ser difundido entre las escuelas de España. El tipo textual de los catecismos había probado su poder de divulgación y de retención en la memoria de los pueblos con la expansión evangelizadora en la América Española. La definición de catecismo viene del griego, katcejismós, que significa, repetición de viva voz. ${ }^{51}$ Con Carlomagno aparecieron los primeros catecismos para enseñar la historia de la creación y finalizar con el Credo y el Padrenuestro. Desde el Concilio de Tortosa en 1429 se mandó observar el uso de los catecismos para el adoctrinamiento de los niños. Para el caso de la Nueva España, el catecismo religioso del padre Ripalda había sido el texto divulgativo que acercó a la población, las enseñanzas de los principales dogmas del cristianismo:
P: ¿Eres cristiano?
R: Sí, por la Gracia de Nuestro Señor Jesucristo.
P: ¿Qué quiere decir cristiano?
R: Hombre de Cristo cuya fe profesó en el bautismo.
P: ¿Quién es Cristo?
R: Dios y hombre verdadero.

Jerónimo Ripalda publicó su catecismo en 1591 y durante todo el periodo colonial, se usó como texto para registrar en la memoria de niños, jóvenes, mujeres y ancianos, las verdades esenciales de la religión católica. Su forma textual —a partir de preguntas y respuestas cortas- permitió su memorización inmediata. El religioso preguntaba, los niños contestaban en coro. Ejemplar método de enseñanza mnemotécnica de gran circulación en las distintas poblaciones de la Nueva España. Posteriormente con el movimiento ilustrado en Europa, salieron a la luz catecismos históricos como el escrito por el sacerdote francés Fleury, o los catecismos que enfatizaron las bondades y virtudes de la casa real, como el publicado en Madrid en 1788 bajo el título Catecismos de los filósofos o sistema de la felicidad y El catecismo de Estado donde Joaquín Lorenzo Villanueva difundió las tesis de la unidad entre la iglesia y la monarquía y la teoría del origen divino de los reyes. Se publicó en 1793, se prohibió con la promulgación de la Constitución de 1812 y volvió a circulación con el regreso de Fernando VII en 1814. Los ejemplares se divulgaron entre las escuelas para ser repasados una y otra vez hasta quedar grabados en la memoria de los pupilos.

\footnotetext{
50 "Catecismo católico politico. Catecismo civil y breve compendio de las obligaciones del español, conocimiento práctico de su libertad y explicación de su enemigo, muy útil en las actuales circunstancias, puesto en forma de diálogo", Anónimo editado alrededor de 1808. Catecismos políticos españoles. Arreglados a las Constituciones del siglo XIX, Madrid, Comunidad de Madrid/Consejería de Cultura/Secretaría General Técnica eds, 1989.

51 Javier Ocampo López, Los catecismos políticos en la independencia de Hispanoamérica. De la monarquía a la república, Tunja, Universidad Pedagógica y Tecnológica de Colombia, 1988.
} 
El que en 1808 se recurriera al catecismo era, con toda seguridad, por la eficacia y rapidez con que las "las grandes verdades" debían ser transmitidas a los diferentes sectores de la población. La pregunta inicial escrita por Jerónimo Ripalda: ¿Eres cristiano?, fue sustituida por la pregunta de identidad: Decid niño ¿cómo os llamáis? La segunda pregunta interrogaba sobre el sentido de la respuesta anterior: ¿Qué quiere decir cristiano? sustituida en 1808 por: ¿Qué quiere decir español? La orientacion de los catecismos de Ripalda y el civil de 1808, estaba en asegurar la única explicación posible sobre los deberes del cristiano, los deberes del español, según el caso.

La crisis dinástica de 1808 obligó por cualquier medio a desafiar a Napoleón. Esa fue la utilidad del catecismo civil al que hemos aludido: establecer las virtudes de Fernando vil y vituperar a Napoleón Bonaparte. Se trató de un catecismo político elaborado por la circunstancia que entonces se vivió. El vituperio a Napoleón fue considerado como una gran verdad que debía propalarse a los cuatro vientos. Hablaba también de misterios como el de la trinidad:

P: ¿Y cuántas naturalezas tiene ese hombre [Napoleón]?

R: Dos: una diabólica y otra humana.

P: ¿Cuántos emperadores hay?

R: Uno verdadero, pero trino en tres personas falsas.

P: ¿Cuáles son?

R: Napoleón, Murat y Godoy.

P: ¿Es más malo uno que otro?

R: No, padre, pues todos tres son iguales.

P: ¿De quién procede Napoleón?

R: Del infierno y del pecado.

P: ¿Y Murat?

R: De Napoleón

P: ¿Y Godoy?

$\mathrm{R}$ : De la intriga de ambos.

Con el liberalismo se editaron catecismos políticos para difundir los nuevos valores de la libertad. Baste mencionar El catecismo político arreglado a la Constitución Política de la Monarquía Española, escrito por Miguel Domingo, reimpreso en Guatemala en 1813, en Lima en 1813 y en Valencia en 1820; o El catecismo político arreglado a la Constitución Política de la Monarquía Española para ilustración del pueblo, instrucción de la juventud y uso de las escuelas de primeras letras, publicado en Córdova en 1820. Durante el absolutismo de Fernando vir la serie de catecismos, libelos, cartillas que explicaban las verdades constitucionales, fue cancelada:

Ha resuelto prohibir la lectura y enseñanza de los expresados catecismos, así en las escuelas como fuera de ellas en todos los pueblos de estos reinos, y mandar que se expida circular a las 
autoridades y justicias de ellos para que procedan a recoger todos los ejemplares de las respectivas ediciones en dichos folletos exigiendo las de los lugares donde se hubiese verificado la impresión. ${ }^{52}$

Como antigua costumbre inquisitorial, se prohibía lo que gozaba de una gran difusión entre la población. En la Nueva España se publicó en 1810 la Memoria cristiano política sobre lo mucho que la Nueva España debe temer de su desunión en partidos $y$ las grades ventajas de puede esperar de su unión y confraternidad entre peninsulares $y$ americanos. Hacia 1820 con el regreso de la Constitución doceañista, después de la experiencia inmediata del restablecimiento del absolutismo en 1814, los voceros del liberalismo se valieron de cualquier palestra para mostrar, en la esfera pública, la generosa Constitución:

... Este derecho, que es conocido en la Constitución con el nombre de igualdad legal, es el mayor de todos los bienes que ella reporta, porque en él estriba esencialmente el equilibrio social ... ya no se oirán más las voces de vasallo y vasallaje, todos serán ciudadanos, aptos para obtener hasta la más alta dignidad de un estado con tal que la patria les reconozca acreedores por sus merecimientos y virtudes. ${ }^{53}$

La pedagogía cívica aprovechó distintos canales de transmisión para divulgar las ventajas del sistema constitucional. Se edificaron monumentos, se izaron banderas en los balcones de las principales ciudades y pueblos de España, se ritualizó con Te Deum y después en las plazas públicas, el juramento a la Constitución. Desde la palestra, quienes defendían la nueva era constitucional eliminaban cualquier signo asociativo con el anticlericalismo. Constitución no era darle la espalda a la religión católica. Quienes se oponían al nuevo orden lo atacaron por donde más dolía a la población: la religión. El argumento era que con la entrada en vigor de la Constitución, se abrirían las puertas a las falsas filosofías que encarnaba el ateísmo:

Dicen a los sencillos y timoratos que religión y constitución son incompatibles, que abolida la Inquisición se perdió la pureza de la fe, y que la impiedad manchará hasta el altar. Que las Cortes, extinguiendo los monacales, han tocado el incensario, han usurpado la jurisdicción de la Iglesia y atacado la disciplina eclesiástica. ${ }^{54}$

\footnotetext{
El fragmento es tomado de Aureo Yepes Castillo, La educación primaria en Caracas en la época de Bolívar, Caracas, Biblioteca de la Academia Nacional de Historia, 1985.

53 Atanasio Lescuna, "Discurso demostrativo de las principales ventajas que deben resultar de la puntual observancia de la Constitución Política de la Monarquía Española”, sancionada por las Cortes Generales y Extraordinarias, y promulgada en Cádiz el 19 de marzo de 1812, Madrid, Imprenta de Álvarez, 1820.

54 "A las Diputaciones Provinciales y jefes políticos de la península dirige el jefe político de la provincia de Palencia el siguiente decreto”, Valladolid, Imprenta de Roldán, 1821.
} 
Las provincias tenían que convencerse de que religión y constitución no eran excluyentes. Periódicos y tertulias fueron canales en que se discutieron y afianzaron argumentos para persuadir a las distintas provincias sobre las ventajas de estar gobernados por el nuevo código divino. Pero la tarea no era sencilla, más si se le dimensiona al lado de la fuerte presencia jacobina, de la reciente ocupación militar napoleónica, de la crisis dinástica y del peso de la tradición monárquica basada en una política de reforzamiento del absolutismo. ${ }^{55}$

La pedagogía cívica liberal impulsó una nueva legitimidad. Por todas partes, a los cuatro vientos, en el rincón de las aulas de primeras letras y universitarias, se debía asegurar que las "grandes verdades" cayeran, una a una, a manera de pregunta y respuesta, como lluvia pertinaz.

P: ¿Qué es Constitución?

R: Una colección ordenada de las leyes fundamentales o políticas de una nación.

P: ¿Qué se entiende por leyes fundamentals?

R: Las que establecen la forma de gobierno, es decir, las que fijan las condiciones en las que unos han de mandar y otros obedecer.

P: ¿Quién tiene la facultad para hacer estas leyes?

$\mathrm{R}$ : La nación por sí sola o por medio de sus representantes o diputados.

P: ¿Tenemos nosotros Constitución?

R: Tan buena que puede hacernos felices si la observamos y contribuimos a que se observe.

P: ¿Quién la ha formado?

R: Las Cortes Generales y Extraordinarias, instaladas el 24 de septiembre de 1810 .

P: ¿La Constitución es una novedad?

R: No. Sus reglas principales habían estado en uso antiguamente, pero como no formaban un cuerpo ni tenían afianzada su observación los interesados en quebrantarla la habían hecho caer en olvido. Las Cortes las han hecho revivir.

P: ¿Quién componía esas Cortes?

\footnotetext{
55 Entre otras de las críticas que recibieron los diputados, se encontraba el argumento de que el poder legislativo se ponía por encima de los otros dos poderes: “¿Los diputados de las Cortes eran al fin más que unos representantes y apoderados de la nación? ¿y quién ha visto en la política, ni en la diplomacia abrogarse tales facultades los apoderados o ministros que en nada cuenten con sus principales? Lo que observamos es lo contrario. Por más que tengan los poderes, en los casos urgentes e imprevistos siempre consultan a sus reyes (...) Estas razones acaso no les parecerán a muchos convincentes por no saber distinguir ni conocer lo que es soberanía por representación o delegación, y lo que es por esencia. Aquella es indudable que la ejercen los representantes de la nación interin la están representando en el Congreso en virtud de legítimos poderes, mas la soberanía no se debe reputar por la absolutamente soberana”. José Clemente Carnicero, El liberalismo convencido por sus mismos escritos o examen crítico de la Constitución Política de la Monarquía Española y de la obra de don Francisco Martínez Marina, Teoría de las Cortes y de otras que sostienen las mismas ideas acerca de la soberanía de la nación, Madrid, Imprenta de Eusebio Aguado, 1830, p. 5.
} 
R: Los representantes de la Nación Española, o sea sus Diputados elegidos libremente por el pueblo español. ${ }^{56}$

Con la consumación de la independencia de México en 1821, apareció el primer catecismo para la enseñanza de las "grandes verdades": unión, independencia y religión. Con el título de Catecismo de la Independencia bajo el seudónimo de Ludovico de Lato Monte, Luis de Mendizábal reproducía, desde la imprenta de Mariano Ontiveros, este primer catecismo dedicado al emperador de México, Agustín de Iturbide. ${ }^{57}$ En 1827 con la nueva forma de gobierno republicana, se dio amplia circulación al Catecismo de República o elementos del gobierno republicano popular federal de la nación mexicana publicado por M. N. Vargas.

Las "grandes verdades" fueron difundidas según el tiempo histórico y el predominio de una determinada forma de gobierno. Con la consumación de la independencia de México se propagó el carácter libertario, emancipador del movimiento iniciado por Hidalgo. Se propagó con fuerza que Hidalgo desde un principio, pretendió la independencia. La iconografía de nuestros grandes muralistas del siglo xx fue tan eficaz como el catecismo antinapoleónico de 1808. Los discursos septembrinos que se pronunciaron en las palestras republicanas enfocaron su lente en la gesta de quienes iniciaron la lucha en el Bajío novohispano el 16 de septiembre de 1810. Desde 1822 se aclaró quiénes fueron los padres de la patria, cuáles fueron sus principales actos de heroismo; se dibujó la maniquea relación con España. En el dibujo se perdió la Isla de León. El águila de Tenochtitlan terminó por imponerse. La nación mexicana, soberana, independiente, republicana se valió de su propia iconografía y lenguaje políticos para hacer creer, como una gran verdad, que su forja se debió a ella misma. El nuevo estado nación requería del artificio para la fábrica de su mitología. El mito de la nación mexicana descansó en su carácter inmanente y eterno, borrando el tiempo histórico, contradictorio, de su invención.

\footnotetext{
56 Granada, Catecismo político arreglado a la Constitución de la Monarquía Española para ilustración del pueblo, instrucción de la juventud, y uso de las escuelas de primeras letras, Reimpreso en la oficina de D. Francisco de Benavides, 1820.

57 Rafael Sagredo Baeza, "Actores políticos en los catecismos patriotas y republicanos americanos, 1810-1827”, en Historia Mexicana vol. XLV, No. 3, México, UNAM, 1996, p. 506. En este artículo, el autor hace un análisis de los vocablos patria, pueblo, soberanía y república a través de dos catecismos chilenos, dos argentinos, dos mexicanos y uno colombiano.
} 


\section{Bibliografía}

Alicia Hernández, La tradición republicana del buen gobierno, México, FCE/El Colegio de México/ Fideicomiso Historia de las Américas, 1993, pp. 24-25.

Antonio Annino, "Ciudadanía versus gobernabilidad republicana en México. Los orígenes de un dilema” en Hilda Sábato (coord.), Ciudadanía política y formación de las naciones. Perspectivas históricas de América Latina, México, FCE/El Colegio de México/Fideicomiso Historia de las Américas, 1999, pp. 62-93.

Archivo Histórico del Estado de Zacatecas, Fondo Poder Judicial, Serie Criminal, Causa formada al subdelegado en Nieves, Juan de Aguilar por insurgente, febrero 17 de 1811.

Arturo Güemes Pineda, "La emergencia de los ayuntamientos constitucionales gaditanos y la sobrevivencia de los cabildos mayas yucatecos, 1812-1824", en J. Ortiz y J. A. Serrano, Ayuntamientos y liberalismo gaditano en México, p. 102.

Aureo Yepes Castillo, La educación primaria en Caracas en la época de Bolivar, Caracas, Biblioteca de la Academia Nacional de Historia, 1985.

Carlos Herrejón Peredo, Morelos. Antología documental y estudio introductorio, México, SEP ed, 1985

Carlos Marichal, De colonia a nación. Impuestos y política en México, 1750-1860, México, El Colegio de México, 2001.

Catecismos políticos españoles. Arreglados a las Constituciones del siglo XIX, Madrid, Comunidad de Madrid/Consejería de Cultura/Secretaría General Técnica eds, 1989.

David Brading, Orbe indiano. De la monarquía católica a la república criolla; Los orígenes del nacionalismo mexicano, México, FCE, 1998.

Eric Van Young, La otra rebelión. La lucha por la independencia de México, México, FCE, 2000.

Ernesto De la Torre Villar, La conciencia nacional y su formación. Discursos cívicos septembrinos, México, UNAM, 1988.

Ernesto de la Torre, La independencia mexicana 3vols., México, Sep-ochentas ed., 1989 Jaime E. Rodríguez, La independencia de la América Española, México, FCE/El Colegio de México/ Fideicomiso Historia de las Américas eds, 1996.

Javier Ocampo López, Los catecismos políticos en la independencia de Hispanoamérica. De la monarquía a la república, Tunja, Universidad Pedagógica y Tecnológica de Colombia, 1988.

John Lynch, Las revoluciones hispanoamericanas, 1808-1826, Barcelona, Ariel ed, 2001.

John Tutino, De la insurrección a la revolución en México. Las bases sociales de la violencia agraria, 1750-1940, México, Era ed, 1990.

José A. Serrano, Jerarquía territorial y transición política. Guanajuato: 1790-1835, México, El Colegio de Michoacán/Instituto Mora eds., 2001.

José Clemente Carnicero, El liberalismo convencido por sus mismos escritos o examen crítico de la Constitución Política de la Monarquía Española y de la obra de don Francisco Martínez Marina, Teoría de las Cortes y de otras que sostienen las mismas ideas acerca de la soberanía de la nación, Madrid, Imprenta de Eusebio Aguado, 1830, p. 5. 
José María Portillo Valdés, Revolución de nación. Orígenes de la cultura constitucional en España, 17801812, Madrid, Centro de Estudios Políticos y Constitucionales ed, 2000, pp. 159-258.

Juan Hernández y Dávalos, Historia de la guerra de Independencia de México 6 vols., I, México, Instituto Nacional de Estudios Históricos de la Revolución Mexicana, 1985.

Manuel Chust e Ivana Frásquet, "Soberanía hispana, soberanía mexicana. México: 1808-1824”, en Manuel Chust (coord.), Doceañismos, constituciones e independencias. La Constitución de 1812 y América, Madrid, MAPFRE ed, 2006, pp. 169-236.

Manuel Chust, La cuestión nacional americana en las Cortes de Cádiz, Valencia, Centro Francisco Tomás y Valiente/ Fundación Instituto Historia Social/UNAM, 1999, p. 57.

Marcello Carmagnani, El Otro Occidente. América Latina desde la invasión europea hasta la globalización, México, FCE/El Colegio de México/Fideicomiso Historia de las Américas eds, 2004.

Mariana Terán Fuentes, "Soberanía, ciudadanía y representación en la experiencia confederal. Zacatecas, 1823-1835" en Alicia Hernández y Mariana Terán (coords.), Federalismo, ciudadanía y representación en Zacatecas, Zacatecas, Universidad Autónoma de Zacatecas/CONACYT eds., 2010, pp. 187-244.

Marta Irurozqui, "De cómo el vecino hizo al ciudadano en Charcas y de cómo el ciudadano conservó al vecino en Bolivia, 1809-1830” en Jaime E. Rodríguez (ed.), Revolución, independencia y las nuevas naciones en América, Madrid, MAPFRE, 2005, pp. 451-484.

Michael T. Ducey, "Elecciones, constituciones y ayuntamientos. La participación popular en las elecciones de la tierra caliente veracruzana, 1813-1835", en J. Ortiz y J. A. Serrano, Ayuntamientos y liberalismo gaditano en México, p. 176.

Miguel Artola, Historia de España. La burguesía revolucionaria (1808-1874), Madrid, Alianza ed, 2006.

Mónica Quijada, “¿Qué nación? Dinámicas y dicotomías de la nación en el imaginario hispanoamericano", en Antonio Annino y François-Xavier Guerra (coords.), Inventando la nación. Iberoamérica. Siglo XIX, México, FCE, 2003, pp. 287-315.

Nettie Lee Benson, La diputación provincial y el federalismo mexicano, México, El Colegio de México, 1992.

Peter Guardino, "El nombre conocido de República. Municipios en Oaxaca. De Cádiz a la primera república federal" en Juan Ortiz y José Antonio Serrano (coords.), Ayuntamientos y liberalismo gaditano en México, El Colegio de Michoacán/Universidad Veracruzana eds, 2007.

Pierre Ronsavallon, Por una historia conceptual de lo político, México, FCE, 2003.

Rafael Sagredo Baeza, "Actores políticos en los catecismos patriotas y republicanos americanos, 1810-1827”, en Historia Mexicana vol. XLV, No. 3, México, UNAM, 1996.

Tomás Pérez Vejo, "El problema de la nación en las independencias americanas: una propuesta teórica”, Mexican Estudies/Estudios Mexicanos vol. 24, No. 2, California University, 2008.

Virginia Guedea, En busca de un gobierno alterno. Los Guadalupes de México, México, UNAM, 1992 
